\title{
United States Should Encourage India to Take a Greater Role in Afghanistan
}

\author{
FOR RELEASE \\ Wednesday \\ August 8, 2012
}

The United States should encourage India to take a greater role in helping to shape a postconflict environment in Afghanistan, according to a new paper from the RAND Corporation.

The analysis comes on the heels of U.S. Secretary of Defense Leon Panetta's own recent recommendation that India play a more-robust role in Afghanistan, including assisting with the training of Afghanistan's military and police forces.

The RAND paper argues that India and Pakistan each have a stake in influencing developments in Afghanistan and that both countries engage in Afghanistan to advance their own respective geopolitical, defense and economic objectives. However, the analysis asserts India has far more to offer Afghanistan than Pakistan does.

India has so far pledged more than \$2 billion in development support, making it Afghanistan's fifth largest aid donor. Pakistan has spent only about $\$ 300$ million. Indian companies also have invested heavily in transportation infrastructure projects, which will help Afghanistan export its products to other countries.

More importantly, India has recently become involved in Afghan security matters, agreeing to provide light weapons and training in counterinsurgency and high-altitude warfare to the Afghan army, air force and police. The RAND analysis recommends that India should consider expanding this support by conducting large-scale military training inside Afghanistan or deploying a limited number of troops to work alongside Afghan forces and remaining U.S./NATO personnel after 2014.

Previously, U.S. policy attempted to limit India's involvement in Afghanistan in order to prevent alienating Pakistan and losing the support it provided for allied counterterrorism and counterinsurgency operations. However, Pakistan's growing unreliability as a committed partner to the United States, combined with U.S. moves to withdraw from Afghanistan by 2014, has altered the perceived importance of this strategic balancing act. The United States now appears to be tilting toward India.

"One of the main differences between India and Pakistan is that India's pursuit of its goals is more likely to help the Afghan people in the long run," said Larry Hanauer, co-author of the paper and a senior international policy analyst with RAND, a nonprofit research organization. "Pakistan, in contrast, is focused almost exclusively on undermining India's influence in the region." 
According to Hanauer and co-author Peter Chalk, Pakistan is not positioned well to boost trade, and it has demonstrated little willingness to take steps designed to improve the lives of ordinary Afghans. In addition, Pakistan has explicitly sought to support hardliners in the Taliban-while undermining more moderate elements willing to negotiate - as a means of swaying the future course of peace talks in a manner that is consistent with its own long-term strategic goals.

Pakistan's ultimate goal is to establish a friendly government in Afghanistan, which would enable Pakistan's military to retreat there in case of an Indian invasion and to use Afghan territory for training Islamist militants to conduct non-attributable attacks on India. This narrowly focused policy obviously has very little to offer either Afghanistan or its neighbors.

In contrast, India's democratic polity, institutionalized decision-making processes, relative internal stability, apolitical military, large consumer base and growing economy make it a far better partner for Afghanistan, according to the analysis.

The paper, "India's and Pakistan's Strategies in Afghanistan: Implications for the United States and the Region," can be found at www.rand.org.

Research for the paper was funded by and conducted within the RAND Center for Asia Pacific Policy, part of International Programs at RAND. The center aims to improve public policy by providing decision-makers and the public with rigorous, objective research on critical policy issues affecting Asia and U.S.-Asia relations.

- $\underline{\text { Share on Facebook3 }}$

- Share on Twitter

- Share on LinkedIn0

\section{About the RAND Corporation}

The RAND Corporation is a research organization that develops solutions to public policy challenges to help make communities throughout the world safer and more secure, healthier and more prosperous 